\title{
Internucleotide Incorporation of Arabinosyladenine into Herpes Simplex Virus and Mammalian Cell DNA ${ }^{1}$
}

\author{
JILL C. PELLING, ${ }^{*, 2}$ JOHN C. DRACH, ${ }^{\dagger}$ AND CHARLES SHIPMAN, JR. ${ }^{*}+* 3$ \\ *Department of Microbiology and Immunology, School of Medicine, †Department \\ of Oral Biology and the Dental Research Institute, School of Dentistry, \\ The University of Michigan, Ann Arbor, Michigan 48109
}

Accepted September 19, 1980

\begin{abstract}
Viral DNA was isolated from lysates of herpes simplex virus type 1-infected cells which had been incubated in the presence of $0.1,1.0$, or $3.2 \mu M\left[{ }^{3} \mathrm{H}\right]$ ara-A. The DNA was purified by isopycnic centrifugation and was enzymatically digested with micrococcal nuclease and spleen phosphodiesterase. The resulting nucleotides and nucleosides were resolved by means of thin-layer chromatography. Examination of the distribution of radioactivity on the chromatograms revealed that $92-96 \%$ of the label was present as nucleotides demonstrating that $\left[{ }^{3} \mathrm{H}\right]$ ara- $\mathrm{A}$ was internally incorporated into viral DNA. Virtually identical results were obtained using DNA isolated from mature virions. Additional analysis of virion DNA using HindIII restriction endonuclease demonstrated that the incorporation of $\left[{ }^{3} \mathrm{H}\right]$ ara- $\mathrm{A}$ into the viral genome was random and did not oceur at preferential sites. The amount of ara-A incorporated into viral DNA from infected cells was compared with the amount incorporated into cellular DNA from uninfected cells. Viral DNA isolated from cells maintained in $0.1,1.0$, or $3.2 \mu M\left[{ }^{3} \mathrm{H}\right]$ ara-A, contained $2.3,9.7$, or 27.5 ara-AMP residues/10,000 dAMP residues, respectively, whereas uninfected cellular DNA contained $4.1,41.0$, or 160 ara-AMP residues $/ 10,000$ dAMP residues, respectively. These data establish that (i) ara-A is not an absolute chain terminator of HSV-1 DNA synthesis, and (ii) the amount of ara-A incorporated into viral DNA is less than the amount incorporated into cellular DNA.
\end{abstract}

\section{INTRODUCTION}

The nucleoside analog, $9-\beta$-D-arabinofuranosyladenine (ara-A) is currently considered to be the drug of choice for the treatment of infections caused by herpes simplex virus type 1 (HSV-1). The drug is effective when applied ophthalmically for herpes simplex keratitis (Pavan-Langston et al., 1975) and when administered systemically for herpes encephalitis (Whitley

\footnotetext{
${ }^{1}$ Portions of this work are included in the dissertation submitted by J.C.P. in partial fulfillment of the requirements for the $\mathrm{Ph} . \mathrm{D}$. degree in Microbiology, awarded by The University of Michigan in December 1979 .

2 Present address: Biology Division, Oak Ridge National Laboratory, P.O. Box Y, Oak Ridge Tenn. 37830 .

${ }^{3}$ To whom reprint requests should be addressed at the Department of Oral Biology, School of Dentistry, The University of Michigan, Ann Arbor, Mich. 48109.
}

et al., 1977). Results reported by several laboratories demonstrate that ara-A acts selectively against virus-infected cells; in vivo the drug lacks toxicity in its antiviral dose range (Kurtz, 1975; Sloan, 1975), and in vitro it exhibits little or no cytotoxicity at drug concentrations which inhibit viral replication (Shannon, 1975). Previous studies in our laboratory have demonstrated that ara- $A$ is a selective inhibitor of viral DNA synthesis in HSVinfected cells (Shipman et al., 1976; Schwartz et al., 1976). The biochemical basis for this selectivity is poorly understood.

One proposed model for the selective antiviral mechanism of action of ara- $A$ involves incorporation of the corresponding arabinosyl nucleotide into replicating DNA such that further DNA synthesis is inhibited. Results published by Müller 
and co-workers (1977a) indicate that the majority of ara-A incorporated into replicating HSV DNA is present at $3^{\prime}$ hydroxyl termini, thereby suggesting that ara-A acts as a chain terminator of viral DNA synthesis. This observation, along with the fact that incorporation of ara-A into mammalian cell DNA is known to occur internally via internucleotide linkage (Plunkett and Cohen, 1975; Müller et al., 1975), led Müller to suggest that the selective inhibition of HSV DNA synthesis by ara-A was due to the two different modes of incorporation of the drug into DNA (Müller et al., 1977a, b). That is, ara-A acts as a chain terminating nucleoside in HSV DNA, but not in mammalian DNA.

In the current study, we have reexamined the question of whether ara-A acts as a chain terminator of HSV DNA synthesis. Ising techniques originally developed for nearest neighbor analysis (Josse et al., 1961) we demonstrate that ara-A is internally incorporated via internucleotide linkage into viral DNA from HSV-infected cells or DNA from mature virions. Additional evidence is presented to show that the internucleotide incorporation is random and that the extent of incorporation is less than that observed in the DNA of uninfected cells.

\section{MATERIALS AND METHODS}

Chemicals. [ methyl- ${ }^{3} \mathrm{H}$ ]Thymidine $(20 \mathrm{Ci} /$ mmol), $9-\beta$-D-arabinofuranosyl $\left[2,8-{ }^{3} \mathrm{H}\right]-$ adenine $(10$ to $15 \mathrm{Ci} / \mathrm{mmol})$ and its $5^{\prime}$-monophosphate $\left(\left[{ }^{3} \mathrm{H}\right]\right.$ ara-AMP) were purchased from New England Nuclear, Boston, Massachusetts. Phosphorus-32 as orthophosphate was obtained from Amersham Corporation, Arlington Heights, Illinois. Pentostatin was a gift of Dr. Harold E. Machamer, Parke, Davis and Company, Detroit, Michigan. Calf thymus DNA was purchased from Worthington Biochemical Corporation, Freehold, New Jersey. $\mathrm{N}-2$ hydroxyethylpiperazine - $N^{\prime}-2$ - ethanesulfonic acid (HEPES) was obtained from Calbiochem-Behring Corporation, La Jolla, California, and agarose (standard grade) from Seakem, Marine Colloids, Inc., Rockland, Maine. CsCl (highly purified) was obtained from Column One, Inc., Ann Arbor,
Michigan. Tris(hydroxymethyl)aminomethane $\mathrm{HCl}$ (Tris) (reagent grade) was purchased from Brae Laboratories, Inc., New York, New York.

HEPES-buffered saline (HBS) and FDTAtrypsin in HBS were prepared as described by Shipman (1969). TES buffer consisted of $30 \mathrm{~m} M$ Tris, $5 \mathrm{~m} M$ EDTA, and $50 \mathrm{mM} \mathrm{NaCl}$ at $\mathrm{pH} 8.0$. Scintillation fluid consisted of $0.25 \%$ 2,5-diphenyloxazole (PPO) (Sigma Chemical Co., St. Louis, Mo.) in toluene, reagent grade.

Enyzmes. Micrococcal nuclease (Code NFCP), 14,000 units/mg, spleen phosphodiesterase (Code SPH) 10-15 units per vial, DNase I, 2200 units $/ \mathrm{mg}$, and ribonuclease A (Code RAF), 3666 units/mg were obtained from Worthington Biochemical Corporation. Snake venom phosphodiesterase (Crotalus atrox venom) and alkaline phosphatase ( $1.1 \mathrm{units} / \mathrm{mg}$ ) were purchased from Sigma Chemical Company. HindIII restriction endonuclease (specific activity $=20,000$ units $/ \mathrm{mg}$ protein) was obtained from New England Biolabs, Beverly, Massachusetts. Proteinase $\mathrm{K}$ was purchased from Beckman Instruments, Inc., Palo Alto, California. Pronase, B grade, nuclease free, was purchased from Calbiochem-Behring Corporation.

Cell culture techniques. Donor calf serum, horse serum, and dialyzed calf serum were obtained from K. C. Biological, Inc., Lenexa, Kansas.

The source of cells, the routine growth and passage of BHK 21/4 cells and KB cells, the techniques used for the enumeration of cells, the determination of cell viability, and the detection of mycoplasma contamination have been described previously (Shipman et al., 1976).

Roller bottle cultures of $\mathrm{KB}$ cells were prepared in plastic roller bottles (Corning Glass Works, Corning, N. Y.) using Eagle's minimal essential medium with Hanks' salts $[\operatorname{MEM}(\mathrm{H})]$ supplemented with $10 \%$ calf serum and $0.35 \mathrm{~g}$ /liter $\mathrm{NaHCO}_{3}$. Methocel (4000 centipoises/sec, Dow Chemical Co., Midland, Mich.) was added at a final concentration of $0.05 \%$ to minimize clumping of cells.

Concentrated $\left[{ }^{3} \mathrm{H}\right]$ ara-A-containing culture medium was routinely preincubated with 
$\mathrm{KB}$ cells to reduce trace contaminants of $\left[{ }^{3} \mathrm{H}\right]$ adenine $(1-2 \%)$ found in commerical preparations of the labeled compound. Stock solutions of $\left[{ }^{3} \mathrm{H}\right]$ ara-A were prepared in $\operatorname{MEM}(\mathrm{H})$ supplemented with $10 \%$ calf serum and the adenosine deaminase inhibitor pentostatin. The medium was incubated over monolayer cultures of uninfected $\mathrm{KB}$ cells using a procedure developed by Schwartz (1975). After a 1-h incubation at $37^{\circ}$, the stock solution was decanted and any detached cells were removed by low-speed centrifugation. The medium was then diluted and used in experiments requiring the presence of $\left[{ }^{3} \mathrm{H}\right]$ ara-A. By using this method, the level of $\left[{ }^{3} \mathrm{H}\right]$ adenine could be reduced from $1-2 \%$ to less than $0.5 \%$.

Virus. The HF strain of HSV type 1 (Flanagan, 1967) was obtained from Gary H. Cohen, University of Pennsylvania. The HSV cloning procedure developed by Klein (1975) was employed to prepare a clonal virus isolate. Subsequent passaging of this cloned isolate at low multiplicity (m.o.i. $=0.01$ ) was carried out in $\mathrm{KB}$ cells to prepare virus stocks of high titer $\left(10^{8}-10^{9} \mathrm{PFU} / \mathrm{ml}\right)$. The propagation and titration of HSV-1 were as described previously (Shipman et al., 1976).

Radiolabeling and isolation of DNA. Purification of $\left[{ }^{3} \mathrm{H}\right]$ ara-A-labeled viral DNA from lysates of HSV-1-infected KB cells was performed as follows. Monolayers of $\mathrm{KB}$ cells were grown to $80 \%$ confluence and then infected with HSV-1 (m.o.i. = 5) in virus growth medium [VGM; MEM (Earle salts) with $0.127 \mathrm{~g} /$ liter L-arginine, buffered with $25 \mathrm{~m} M$ HEPES $\mathrm{pH}=7.4$ at $22^{\circ}$ ), and supplemented with $10 \%$ calf serum.] The virus was allowed to adsorb for $1 \mathrm{hr}$ at $37^{\circ}$, then each monolayer was rinsed twice with warm VGM without serum. VGM containing 0 , $0.1,1.0$, or $3.2 \mu M\left[{ }^{3} \mathrm{H}\right]$ ara- $\mathrm{A}$ was added to the monolayers and the flasks were incubated for an additional $18 \mathrm{hr}$. Pentostatin $(1 \mu \mathrm{g} / \mathrm{ml})$ was included in the drug-containing medium to prevent deamination of araA to arabinosylhypoxanthine (ara-H). After $18 \mathrm{hr}$, the cells were detached by vigorously shaking the flasks. The harvested cells were pelleted by centrifugation at $100 \mathrm{~g}$ for $15 \mathrm{~min}$, and each pellet was resuspended in
TES buffer. Pronase and sarkosyl were added to the cell suspensions at final concentrations of $2 \mathrm{mg} / \mathrm{ml}$ and $0.5 \%$, respectively. The cell lysates were digested for $2 \mathrm{hr}$ at $37^{\circ}$, then mixed with cesium chloride in TES (final refractive index $=1.3996$ ). Viral and cellular DNAs were separated by isopycnic density gradient centrifugation in a Ti60 rotor for $65 \mathrm{hr}$ at $100,000 \mathrm{~g}$. Each gradient was fractionated and the fractions containing HSV-1 DNA were pooled and recentrifuged in a second $\mathrm{CSCl}$ gradient to further purify the viral DNA. We estimate that contamination of viral DNA by cellular DNA was $<3 \%$. Fractions containing viral DNA were pooled and dialyzed at $4^{\circ}$ against $1 \mathrm{mM}$ Tris buffer, $\mathrm{pH}$ 8.6.

Viral DNA was purified from mature virions as follows. Monolayer cultures of $\mathrm{KB}$ cells were grown in plastic roller bottles to $80 \%$ confluency, at which time the cultures were infected with HSV-1 (m.o.i. $=5)$. After a 1-hr incubation period at $37^{\circ}$, unadsorbed virus was removed by rinsing the cell sheet twice with warm medium. Seventy milliliters of VGM supplemented with $10 \%$ calf serum plus $\left[{ }^{3} \mathrm{H}\right]$ ara-A and pentostatin $(1 \mu \mathrm{g} / \mathrm{ml})$ was added to each $490 \mathrm{~cm}^{2}$ roller bottle. The roller bottles were incubated for $36 \mathrm{hr}$ to permit maximum production of supernatant virus. Roller bottles were shaken to detach cells, and the infected cells were pelleted by centrifugation at $5000 \mathrm{rpm}$ for $10 \mathrm{~min}$ in a Beckman J-21 preparative centrifuge to remove cells and cell debris. The supernatant fluid was then centrifuged at $15,000 \mathrm{rpm}$ for $20 \mathrm{~min}$ at $4^{\circ}$ in the J-21 centrifuge to pellet mature virions. The virus pellet was resuspended in $0.9 \mathrm{ml}$ lysing buffer $(0.1 \mathrm{M} \mathrm{NaCl}, 0.1 \mathrm{M}$ HEPES, $0.02 M$ EDTA, pH 7.4), to which was added $100 \mu \mathrm{l} 20 \%$ sarkosyl, $50 \mu \mathrm{l} 10 \%$ sodium dodecyl sulfate, and $50 \mu \mathrm{g}$ ribonuclease A per milliliter. The viral lysate was digested for $1 \mathrm{hr}$ at $37^{\circ}$, after which time $25 \mu l$ proteinase $\mathrm{K}(10 \mathrm{mg} / \mathrm{ml}$ stock preparation) was added and the lysate digested for $2 \mathrm{hr}$ at $55^{\circ}$. The digest was then added to TES buffer containing cesium chloride at a final refractive index of 1.3996 and centrifugation was carried out in a Ti60 rotor at $15^{\circ}$ for $65 \mathrm{hr}$ at $100,000 \mathrm{~g}$. Those fractions containing the viral DNA peak were pooled, 
and dialyzed at $4^{\circ}$ against three changes of $1 \mathrm{~m} M$ Tris, $\mathrm{pH} 8.6$.

The specific activities of viral DNA preparations were computed by determining the amounts of radioactivity and of DNA in aliquots of interest. Counts per minute were determined in a Beckman LS8100-Texas Instruments 733ASR liquid scintillation spectrometer system. Disintegrations per minute were calculated by means of a computer program (SUPERLIQ; Schwartz, 1975) according to the Compton edge method described by Horrocks (1974). The DNA content of companion aliquots was determined using a modification of the diphenylamine assay developed by Burton (1968).

Cellular DNA which had been labeled with $\left[{ }^{3} \mathrm{H}\right]$ ara-A was purified from uninfected $\mathrm{KB}$ cells grown in suspension cultures. Briefly, $\mathrm{KB}$ cells from a log-phase suspension culture were used to seed four $100-\mathrm{ml}$ spinner flasks at a cell density of $3 \times 10^{5}$ cells $/ \mathrm{ml}$. The suspension cultures were allowed to equilibrate for $1 \mathrm{hr}$. Following equilibration, $5.0 \mathrm{ml}$ of medium supplemented with $\left[{ }^{3} \mathrm{H}\right]$ ara-A and pentostatin $(1 \mu \mathrm{g} / \mathrm{ml})$ was added to each culture to yield final concentrations of $0,0.1,1.0$, or $3.2 \mu M\left[{ }^{3} \mathrm{H}\right]-$ ara-A in a volume of $60 \mathrm{ml}$. At the time of drug addition and $18 \mathrm{hr}$ later, aliquots $(0.5 \mathrm{ml})$ were removed from the spinner flasks and pipetted into an equal volume of ice-cold HBS for use in determining the specific activity of the KB cell DNA. Cells were pelleted at $300 \mathrm{~g}$ for $10 \mathrm{~min}$ at $4^{\circ}$, the medium was decanted, and the samples were stored at $-20^{\circ}$ for the diphenylamine assay and radioactivity determinations.

The amount of label incorporated into cell DNA was determined as follows. The pelleted cells from $0.5-\mathrm{ml}$ aliquots were thawed and resuspended in $0.8 \mathrm{ml}$ lysing buffer. The cells were lysed with $100 \mu \mathrm{l}$ of $20 \%$ sarkosyl and $50 \mu \mathrm{l}$ of sodium dodecyl sulfate $(10 \%)$. Ribonuclease $\mathrm{A}$ was added to a final concentration of $50 \mu \mathrm{g} / \mathrm{ml}$ and the mixture was incubated at $37^{\circ}$ for $1 \mathrm{hr}$. Twenty-five microliters of proteinase $\mathrm{K}(10 \mathrm{mg} / \mathrm{ml})$ was added and the cell lysate was digested for $2 \mathrm{hr}$ at $55^{\circ}$. Fifty-microliter samples were spotted onto filter papers and washed three times in ice-cold 5\% trichloroacetic acid, twice in ethanol, and once in diethyl ether. The filter papers were counted in a liquid scintillation spectrometer using a toluene-based cocktail containing $3 \%$ Protosol and $0.4 \%$ Omnifluor (New Fngland Nuclear, Boston, Mass.). The DNA content of KB cells from suspension cultures was determined using a modification of the diphenylamine assay. On the day of the assay, the washed, frozen $0.5-\mathrm{ml}$ cell pellets were thawed and $1.0 \mathrm{ml}$ of $1 \mathrm{~N}$ $\mathrm{HClO}_{4}$ was added to each tube. Samples were vortexed to resuspend the cell pellets, and the diphenylamine assay procedure was carried out as described previously for purified dialyzed DNA.

Enzymatic digestion and chromatographic analysis of DNA. Purified viral and cellular DNA were enzymatically digested to 3 -mononucleotides and terminal nucleosides with micrococcal nuclease and spleen phosphodiesterase using a modification of techniques published by Josse and co-workers (1961) and Müller and others (1975). Five to ten micrograms of DNA in a $200-\mu$ l volume were digested with 0.6 $\mu \mathrm{g}$ micrococcal nuclease (14,000 units/mg) in $1 \mathrm{~m} M$ Tris, $\mathrm{pH} 8.6$, supplemented with 1 $\mu \mathrm{l}$ of pentostatin $(1 \mathrm{mg} / \mathrm{ml})$ and $10 \mu \mathrm{l}$ of $0.1 \mathrm{M}$ $\mathrm{CaCl}_{2}$. The $\mathrm{pH}$ of the digestion mixture was adjusted to 9.5 with $0.1 \mathrm{~N} \mathrm{NaOH}$. After a 2-hr incubation period at $37^{\circ}$, the mixture was further digested for three 1-hr periods at $37^{\circ}$ with $15 \mu \mathrm{g}$ of spleen phosphodiesterase in consecutive additions, $\mathrm{pH}$ 7.0. EDTA (final concentration of $1 \mathrm{mM}$ ) was added to inhibit phosphatases which were present as contaminants in the phosphodiesterase preparation. The $\mathrm{pH}$ was adjusted to $6.5-7.0$ with $1 \mathrm{~N} \mathrm{HCl}$. The digested DNA was resolved into mononucleotides and nucleosides by means of thin-layer chromatography on silica gel plates (Analtech, Ine., Newark, Del.) as previously described (Schwartz and Drach, 1978).

Viral DNA also was digested to $\tilde{\sigma}^{\prime}$ mononucleotides by sequential enzymatic hydrolysis with DNase I and snake venom phosphodiesterase (Plunkett and Cohen, 1975). Samples of DNA $(200 \mu \mathrm{l})$ were added to tubes containing $25 \mu \mathrm{l}$ of $0.1 \mathrm{M} \mathrm{MgCl}_{2}$, and $25 \mu$ l DNase I (200 units) in $1 \mathrm{~m} M$ Tris, pII 7.0. Pentostatin was added to a final 
concentration of $1 \mu \mathrm{g} / \mathrm{ml}$. The $\mathrm{pH}$ was adjusted to 7.8 and the digestion mixture was incubated for $2 \mathrm{hr}$ at $37^{\circ}$. Snake venom phosphodiesterase was added (0.1 $\mathrm{mg}$ in $65 \mu \mathrm{l} \mathrm{m} M$ Tris, $\mathrm{pH} 8.8$ ) and the $\mathrm{pH}$ was adjusted to 8.8 with $0.1 \mathrm{~N}$ sodium hydroxide. After an incubation period of $2-3 \mathrm{hr}$ at $37^{\circ}$, the digest was precipitated with 2 vol of absolute ethanol at $-20^{\circ}$, and samples were analyzed by two-dimensional thin-layer chromatography on polyethyleneimine (PEI)-cellulose plates, as detailed previously (Schwartz and Drach, 1978). Plates were sectioned into counting vials and each section was extracted with $2 \mathrm{ml}$ of $0.1 \mathrm{~N} \mathrm{HCl}$ in methanol for $1 \mathrm{hr}$ or more at room temperature. Scintillation cocktail was added and samples were counted to determine the number of disintegrations per minute associated with each nucleotide.

When necessary, viral or cellular DNA, previously digested to mononucleotides, was further digested to nucleosides by alkaline phosphatase treatment (Müller et al., 1975). Aliquots $(100 \mu \mathrm{l})$ of digested DNA were treated with 0.55 unit of bovine alkaline phosphatase $(0.1 \mathrm{unit} / \mathrm{mg}$ ) for $16 \mathrm{hr}$ at $37^{\circ}$. Pentostatin was added to a concentration of $1 \mu \mathrm{g} / \mathrm{ml}$. The $\mathrm{pH}$ of the enzymatic reaction was adjusted to 9.0 with $0.1 \mathrm{~N}$ sodium hydroxide. After digestion, samples were analyzed by thin-layer chromatography on silica gel plates, as described previously (Schwartz and Drach, 1978).

Restriction endonuclease analysis of HSV DNA. HSV-1 DNA, isolated from purified mature virions, was digested with the restriction endonuclease HindIII and subjected to electrophorcsis through $0.6 \%$ agarose tube gels using a procedure published by Wagner and co-workers (Stringer et al., 1978). After electrophoresis, gels were sliced into 1-mm sections using a semiautomatic gel slicer designed by Mr. Josef Biela, Mechanical Instrumentation Shop, Division of Biological Sciences, University of California at Irvine, Irvine, California. Each gel slice was placed in a glass scintillaation counting vial, and the agarose was hydrolyzed in $0.5 \mathrm{ml}$ of $10 \%$ perchloric acid by heating for $3 \mathrm{~min}$ at $78^{\circ}$. A $10-\mathrm{ml}$ aliquot

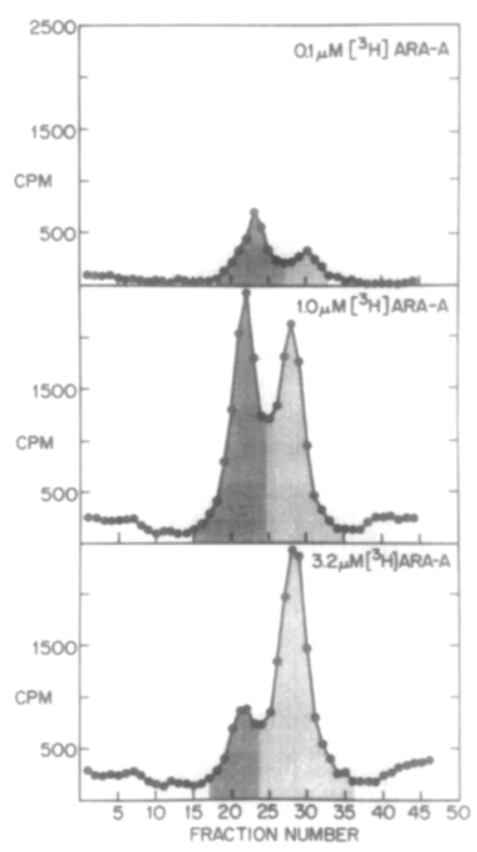

FIG. 1. Separation by isopycnic centrifugation in $\mathrm{CsCl}$ density gradients of $\left[{ }^{3} \mathrm{H}\right]$ ara- $\Lambda$-labeled viral and cellular DNA. The lightly shaded fractions represent the less dense cellular DNA while the more heavily shaded fractions represent viral DNA.

of ACS scintillation cocktail (Amersham Corp.) was added to each vial and the samples were counted in a scintillation spectrometer.

\section{RESULTS}

Incorporation of $\left[{ }^{3} \mathrm{H}\right]$ Arabinosyladenine into Viral DNA Isolated from Infected Cell Lysates

In order to determine if ara-A is incorporated into HSV-1 DNA, viral DNA was isolated from lysates of infected $\mathrm{KB}$ cells which had been incubated in the presence of $\left[{ }^{3} \mathrm{H}\right]$ ara-A. Figure 1 illustrates the separation of viral and cellular DNA and shows the effects of increasing concentrations of ara-A (and consequently, the amount of radioactive label) in the cell culture medium. At $0.1 \mu M\left[{ }^{3} \mathrm{H}\right]$ ara-A (upper panel, the concentration of radioactive isotope was low $(1.1 \mu \mathrm{Ci} / \mathrm{ml})$, resulting in little labeling of viral and cellular DNA. At $1.0 \mu M\left[{ }^{3} \mathrm{H}\right]$ ara-A $(11.1 \mu \mathrm{Ci} / \mathrm{ml})$ (middle 
TABLE 1

Use of EDTA to Inhibit Contaminating Phosphatases in a Commercial Preparation of SPLEEN PHOSPHOdIESTERASE"

\begin{tabular}{lc}
$\begin{array}{c}\text { Concentration of } \\
\text { EDTA }(\mathrm{m} M)\end{array}$ & $\begin{array}{c}\text { Percentage of }\left[{ }^{3} \mathrm{H}\right] \text { ara-AMP } \\
\text { converted to }\left[{ }^{3} \mathrm{H}\right] \text { ara-A }\end{array}$ \\
\hline 0 (Control) & 13.3 \\
0.001 & 1.6 \\
0.100 & 1.2 \\
10 & 1.3 \\
20 & 1.0 \\
\hline
\end{tabular}

" $2 \mu \mathrm{Ci}$ of $\left[{ }^{3} \mathrm{H}\right]$ ara-AMP in $\left.200 \mu\right]$ of $1 \mathrm{mM}$ Tris ( $\mathrm{pH} 7.0$ ) were incubated at $37^{\circ}$ for $3 \mathrm{hr}$ with $0.045 \mathrm{mg}$ spleen phosphodiesterase (Worthington Biochemical Corp.). EDTA was added prior to incubation to yield the final concentrations indicated above. Following incubation, $4 \mu$ l of each mixture was chromatographed on silica gel plates as described under Materials and Methods. The plates were fractionated and the percentage of radioactivity associated with the dephosphorylated ara-A fraction was determined with a scintillation spectrometer.

panel), increased incorporation of isotope was seen in both viral and cellular DNA. The antiviral activity of $1.0 \mu M$ ara-A is minimal at this concentration (Schwartz et al., 1976), and little preferential inhibition of viral DNA was observed. The highest concentration of $\left[{ }^{3} \mathrm{H}\right]$ ara-A used, $3.2 \mu M$ or $35.6 \mu \mathrm{Ci} / \mathrm{ml}$ (lower panel), is close to the $50 \%$ inhibitory concentration of the drug (Schwartz et al., 1976), and resulted in a selective decrease in the peak size of viral DNA compared to cellular DNA. Cesium chloride gradient fractions corresponding to the viral DNA peaks were pooled, centrifuged again in $\mathrm{CsCl}$ density gradients to further purify the viral DNA, and subjected to enzymatic digestion with micrococcal nuclease and spleen phosphodiesterase.

Early experiments which used micrococcal nuclease and spleen phosphodiesterase to digest $\left[{ }^{3} \mathrm{H}\right]$ ara-A-labeled DNA suggested that one or both of the enzymes contained contaminating phosphatases which dephosphorylated nucleoside $3^{\prime}$-monophosphates to the corresponding nucleosides. Subsequent tests were carried out in which $\left[{ }^{3} \mathrm{H}\right]$ ara-AMP was exposed to micrococcal nuclease or spleen phosphodiesterase and the amount of $\left[{ }^{3} \mathrm{H}\right]$ ara- $\mathrm{A}$ produced was monitored by thin-layer chromatography on silica gel plates. These experiments demonstrated that the micrococcal nuclease was free of phosphatases(s), but that the spleen phosphodiesterase preparation contained considerable phosphatase activity (data not shown). Because phosphatases are inhibited by EDTA whereas phosphodiesterase is activated (Hilmoe, 1960), EDTA was included in the enzymatic digestion mixture. Table 1 presents the results of an experiment carried out to determine the optimal concentration of EDTA. When no EDTA was included, $13 \%$ of the $\left[{ }^{3} \mathrm{H}\right]$ ara-AMP in the incubation mixture was dephosphorylated to ara-A by contaminating phosphatase(s) in the spleen phosphodiesterase. Addition of as little as $1 \mu M$ EDTA effectively inhibited the phosphatase activity. A concentration of 1 $\mathrm{m} M$ was chosen as an appropriate level of EDTA for use in the DNA digestion mixtures. This concentration inhibited contaminating phosphatase activity without affecting the activity of spleen phosphodiesterase (data not shown).

Using $1 \mathrm{~m} M$ EDTA in appropriate digestion mixtures, the purified viral DNA labeled with $\left[{ }^{3} \mathrm{H}\right]$ ara- $\mathrm{A}$ was now enzymatically cleaved with micrococcal nuclease and spleen phosphodiesterase. The resulting DNA digests were resolved into 3 '-mononucleotides and nucleosides by means of silica gel thin-layer chromatography. Figure 2 (upper panel) is a representative profile of the distribution of radioactivity on a silica gel plate used to chromatograph a sample of digested viral DNA labeled with $1.0 \mu M\left[{ }^{3} \mathrm{H}\right]$ ara-A. Over $95 \%$ of the tritium label was detected at the origin where nucleotides would remain. Similar profiles were obtained when viral DNA isolated from cells incubated with 0.1 and 3.2 $\mu M\left[{ }^{3} \mathrm{H}\right]$ ara-A were digested and chromatographed (data not shown). Only $0.5-2.0 \%$ of the counts were detected in the ara- $A$ fraction at each drug concentration. In a control experiment using digested DNA labeled with $\left[{ }^{3} \mathrm{H}\right]$ thymidine, $1.5 \%$ of the radioactivity on the silica gel plate migrated with 
the nucleoside thymidine. The close correspondence of these two percentage values indicates that the radioactivity associated with the ara-A fraction in Fig. 2 (upper panel) represents the contribution from strands of DNA which happen to have 3 -terminal ara-A moieties at the time of DNA isolation or from random nicking during DNA purification. It appears, therefore, that ara-A was incorporated internally into viral DNA via internucleotide linkage and was not acting as an absolute chain terminator.

To verify that the radioactivity at the origin on the silica gel chromatogram shown in Fig. 2 (upper panel) was from arabinosyl nucleotides, labeled material was further digested to nucleosides with alkaline phosphatase and chromatographed on silica gel plates. The chromatographic distribution of radioactivity of a representative alkaline phosphatase digest is illustrated in Fig. 2 (lower panel). Similar profiles were obtained when viral DNA labeled with 0.1 or $3.2 \mu M\left[{ }^{3} \mathrm{H}\right]$ ara-A was digested and chromatographed (data not shown). As can be seen in the figure, nearly all of the radioactivity was associated with ara-A and not with ribosyl, deoxyribosyl, or other arabinosyl nucleosides. The small percentage of counts present in fraction " 6 " with the deoxyadenosine standard presumably originated from the $0.5 \%\left[{ }^{3} \mathrm{H}\right]$ adenine contaminant in the commercial preparation of $\left[{ }^{3} \mathrm{H}\right]$ ara-A.

Having established that ara-A was internally incorporated into HSV-1 DNA from infected $\mathrm{KB}$ cell lysates, further analysis was performed to determine whether the amount of ara-A incorporated into viral DNA increased as the concentration of ara-A in the external medium was increased. The specific activities of samples of viral DNA, purified previously from cells infected with HSV-1 and labeled with $\left[{ }^{3} \mathrm{H}\right]$ ara- $\mathrm{A}$, were determined as described under Materials and Methods. The number of ara-AMP molecules incorporated per 10,000 molecules of deoxyadenosine monophosphate at each drug level was then computed using the formula shown in footnote $b$ in Table 2 . Both the specific

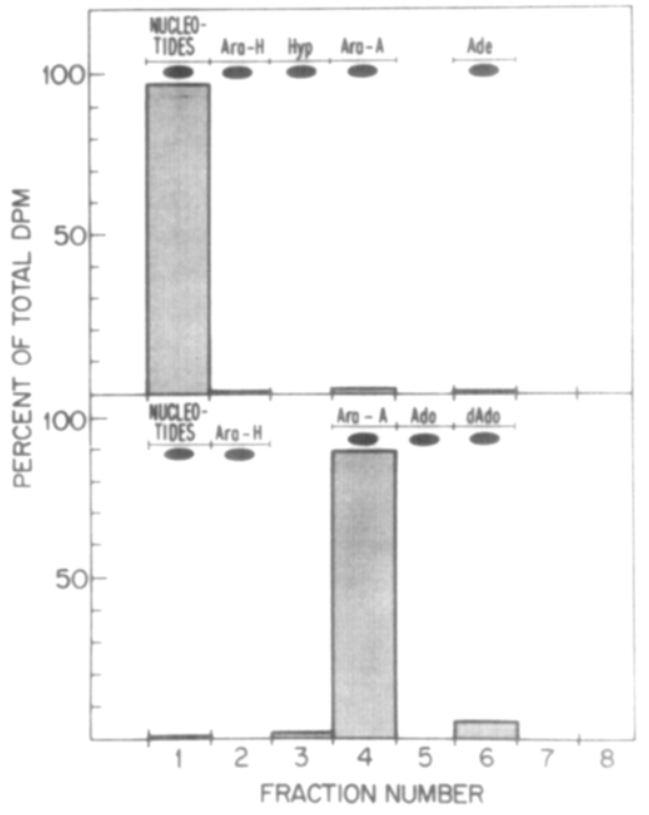

FIG. 2. Silica gel thin-layer chromatograms of enzymatically digested HSV-1 DNA. Viral DNA labeled with $1.0 \mu M\left[{ }^{3} \mathrm{H}\right]$ ara- $A$ was isolated from infected $\mathrm{KB}$ cells (see Fig. 1) and was digested with micrococcal nuclease and spleen phosphodiesterase (upper panel) or both enzymes followed by alkaline phosphatase (lower panel). Approximately $8 \times 10^{3} \mathrm{dpm}$ were spotted at the origin and chromatographed as described under Materials and Methods. The position of unlabeled standards is indicated at the top. Migration is from left to right.

activities of the $\left[{ }^{3} \mathrm{H}\right]$ ara-A-labeled viral DNA and the corresponding number of ara-AMP residues incorporated at each drug concentration are presented in Table 2. From these values it is evident that the number of ara-AMP molecules incorporated into viral DNA increased as the concentration of ara-A in the external medium was increased.

\section{Incorporation of $\left[{ }^{3} \mathrm{H}\right]$ Arabinosyladenine into HSV-1 DNA Isolated from Mature Virions}

Although the studies described above demonstrate the incorporation of ara- $A$ into viral DNA obtained from infected cell lysates, the possibility exists that viral DNA which contains the fraudulent 
TABLE 2

INCORPORATION OF ARA-A INTO ViRAL AND CELlular DNA

\begin{tabular}{|c|c|c|c|c|}
\hline \multirow{2}{*}{$\begin{array}{c}\text { Concentration of } \\
\text { ara- } \mathrm{A}(\mu M)\end{array}$} & \multicolumn{2}{|c|}{ Specific activity of DNA $(\mathrm{dpm} / \mu \mathrm{g})^{t i}$} & \multicolumn{2}{|c|}{$\begin{array}{l}\text { Number of ara-AMP molecules } \\
\text { incorporated per } 10^{4} \mathrm{dAMP} \text { molecules }\end{array}$} \\
\hline & Viral & Cellular & Viral & Cellular \\
\hline$--\overline{0}-$ & $\overline{28}+\overline{0}-\overline{103 \mathrm{c}}$ & $82+03 \times 10^{3}$ & 29 (2) 940 d & \\
\hline $\begin{array}{l}0.1 \\
1.0\end{array}$ & $1.3 \pm 0.04 \times 10^{4}$ & $8.2 \pm 1.0 \times 10^{4}$ & $9.7(8.6-10.8)$ & $41.0(36.0-46.0)$ \\
\hline 3.2 & $3.4 \pm 0.5 \times 10^{4}$ & $3.2 \times 10^{5}$ & $27.5(23.5-31.5)$ & 160.0 \\
\hline
\end{tabular}

"These values have been corrected for the amount of radioactive label present in the form of $\left[{ }^{3} \mathrm{H}\right] \mathrm{dAMP}$ (see Fig. 2).

"The number of ara-AMP molecules incorporated into HSV-1 DNA or KB cell DNA per dAMP residue was computed by means of the following formula:

specific activity of viral or cellular DNA

$\times\left[1 \mu \mathrm{Ci} /\left(2.22 \times 10^{6} \mathrm{dpm}\right)\right] \times\left(1 \times 10^{-3} \mathrm{~mol} / \mathrm{mmol}\right)$

specific activity of $\left[^{3} \mathrm{H}\right]$ ara-A $\times\left[\left(6.023 \times 10^{23}\right.\right.$ molecules $) / \mathrm{mol}$ of ara-A]

number of dAMP molecules/ $\mu \mathrm{g}$ of viral or cellular DNA

The following assumptions, calculations, and numerical values have been used in evaluating the formula: (i) One mierogram of double-stranded DNA contains $3.08 \times 10^{-9}$ mol of nucleotide. (ii) $3.08 \times 10^{-9} \mathrm{~mol}$ nucleotide $/ \mu \mathrm{g}$ DNA $\times 6.023 \times 10^{23}$ nucleotides $/ \mathrm{mol}=1.85 \times 10^{15}$ nucleotides $/ \mu \mathrm{g}$ DNA. (iii) HSV-1 DNA has a guanine-cytosine content of $67 \%$, whereas KB cell DNA has a guanine-cytosine content of $42 \%$ (Cohen et al., 1971). (iv) In $1 \mu \mathrm{g}$ of HSV DNA there are, therefore, $6.10 \times 10^{14}$ adenine-thymine base pairs of which one-half $\left(3.05 \times 10^{14}\right)$ are dAMP, whereas in $1 \mu \mathrm{g}$ of KB cellular DNA, there are $1.075 \times 10^{15}$ adenine-thymine base pairs, of which one-half $\left(5.377 \times 10^{14}\right)$ are dAMP. (v) The specific activities of the $\left[{ }^{3} \mathrm{H}\right]$ ara-A used in experimental determination of the specific activities of viral and cellular DNA are $11.0 \times 10^{6} \mu \mathrm{Ci} / \mathrm{mmol}$ and $10.1 \times 10^{6} \mu \mathrm{Ci} / \mathrm{mmol}$, respectively.

"Arithmetic mean \pm SEM.

"Arithmetic mean and range of means using \pm SEM for the specific activity of viral or cellular DNA.

"SEM not shown. The strategy of computing the standard error of a ratio (DPM/ $\mu \mathrm{g}$ DNA) and a subsequent range of values is not valid when the denominator approaches zero.

arabinosyl nucleotide is never packaged into progeny virions. To test this possibility, we have analyzed HSV-1 DNA isolated from mature enveloped virions.

Virus particles were isolated from the supernatant fluid of $\mathrm{HSV}$-1-infected $\mathrm{KB}$ cell monolayer cultures which had been incubated in the presence of $1.0 \mu M\left[{ }^{3} \mathrm{H}\right]-$ ara-A. This concentration of $\left[{ }^{3} \mathrm{H}\right]$ ara- $\mathrm{A}$ was selected to permit a high level of radioactivity in the external medium (11.1 $\mu \mathrm{Ci} / \mathrm{ml})$ with minimal inhibition of viral DNA synthesis (see Fig. 1, middle panel). Viral DNA was extracted from supernatant virions and purified by centrifugation in $\mathrm{CsCl}$ isopycnic density gradients, as described under Materials and Methods. A typical profile from a $\mathrm{CsCl}$ gradient is shown in the inset to Fig. 3. A prominent peak of viral DNA (fractions 16-26) and a small peak of cellular DNA (fractions 2729) can be seen. Only fractions $18-22$ of the viral DNA peak (shaded area) were pooled, in order to prevent contamination by $\mathrm{KB}$ cell DNA. The purified DNA was digested with micrococcal nuclease and spleen phosphodiesterase, followed by separation of nucleotides and nucleosides on silica gel thin-layer chromatograms. The distribution of total dpm on the fractionated plate is illustrated in Fig. 3 (upper panel). Nincty-seven percent of the disintegrations per minute remained at the origin as nucleoside monophosphates and only $2 \%$ of the counts migrated with the unlabeled araA standard. Thus, it appears that viral 


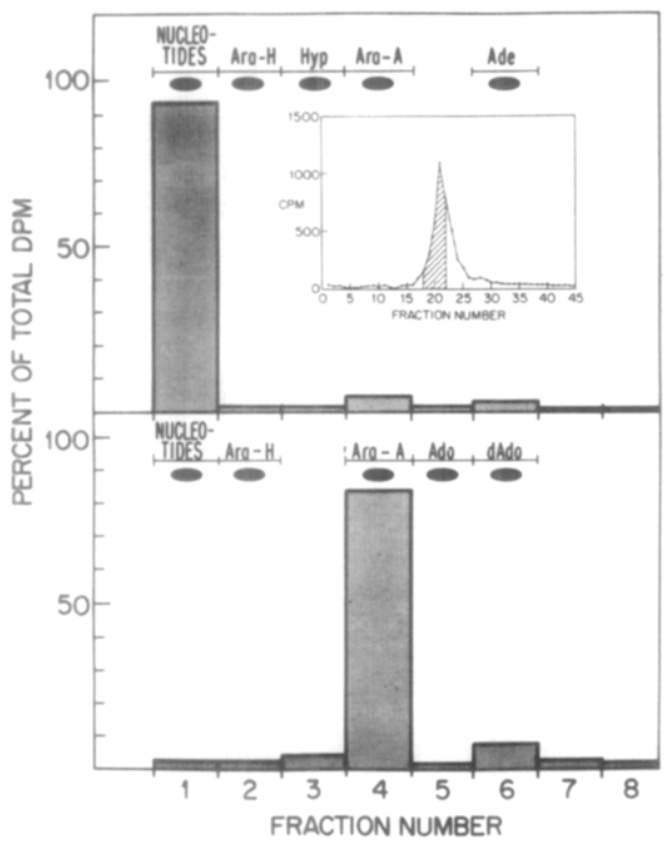

FiG. 3. Silica gel thin-layer chromatograms of enzymatically digested HSV-1 DNA from mature virions. Viral DNA labeled with $1.0 \mu M\left[{ }^{3} \mathrm{H}\right]$ ara-A was isolated from a $\mathrm{CsCl}$ density gradient (see inset) and was digested with micrococcal nuclease and splcen phosphodiesterase (upper panel) or both enzymes followed by alkaline phosphatase (lower panel). Chromatographic conditions were identical to those described in the legend to Fig. 2.

DNA containing incorporated ara-A had been packaged into virions with subsequent release of the mature virions into the surrounding supernatant medium. To verify that the radioactivity observed at the origin of the silica gel plate was arabinosyl and not ribosyl or deoxyribosyl nucleotides, the nuclease-treated DNA was digested further with alkaline phosphatase as described previously. Figure 3 (lower panel) illustrates that nearly all of the radioactivity was associated with the unlabeled ara-A standard when chromatographed on a silica gel plate. Thus, as was the case with viral DNA isolated from infected cell lysates, it appears that ara-A was internally incorporated into viral DNA via internucleotide linkage and was not acting as an absolute chain terminator.
Confirmation of the above results was obtained by digesting DNA from mature virions to $5^{\prime}$-nucleotides and characterizing the nucleotides by thin-layer chromatography. Viral DNA isolated from whole virions (as depicted in the inset to Fig. 3) was digested with DNase 1 and snake venom phosphodiesterase. The resulting 5 'mononucleotides were separated by twodimensional thin-layer chromatography on polyethyleneimine (PEI)--cellulose plates. Figure 4 shows the separation of unlabeled arabinosyl, deoxyribosyl, and ribosyl mono-, di-, and triphosphate standards visualized under ultraviolet light. The number of disintegrations per minute associated with the monophosphates of ara-A, deoxyadenosine, and ara- $\mathrm{H}$ are indicated; less than $10 \mathrm{dpm}$ were associated with all other nucleotides. The observation that approximately $90 \%$ of the total radioactivity on the PEI plate was associated with ara-AMP supports the results obtained with the micrococcal nuclease-spleen

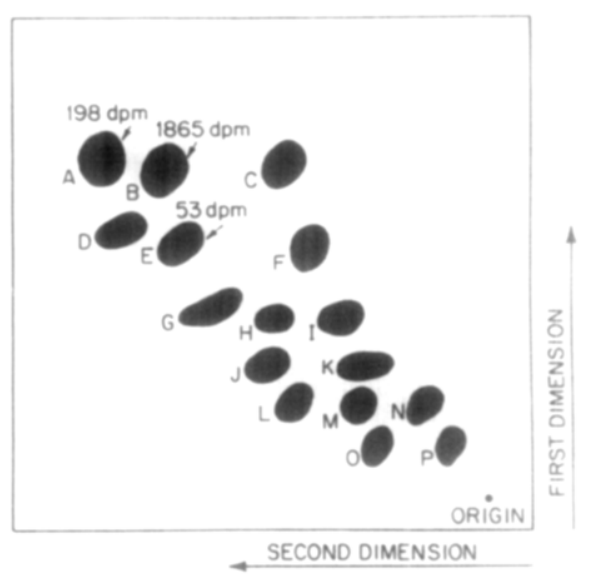

FIG. 4. Thin-layer chromatographic separation of adenine and hypoxanthine 5 '-nucleotides on a PEIcellulose plate. $\left[{ }^{3} \mathrm{H}\right.$ ] ara-A labeled HSV-1 DNA isolated from mature virions (as depicted in the inset to Fig. 3) was digested with DNase I and snake venom phosphodiesterase and chromatographed. The number of disintegrations per minute associated with labeled nucleotides is indicated by arrows. Label associated with all other nucleotides was $10 \mathrm{dpm}$ or less. A, dAMP; B, ara-AMP; C, AMP; D, dIMP; E, ara-HMP; F, IMP; G, dADP; H, ara-ADP, I, ADP; J, dIDP; K, IDP; L, dATP; M, ara-ATP, N, ATP; O, dITP; P, ITP. 


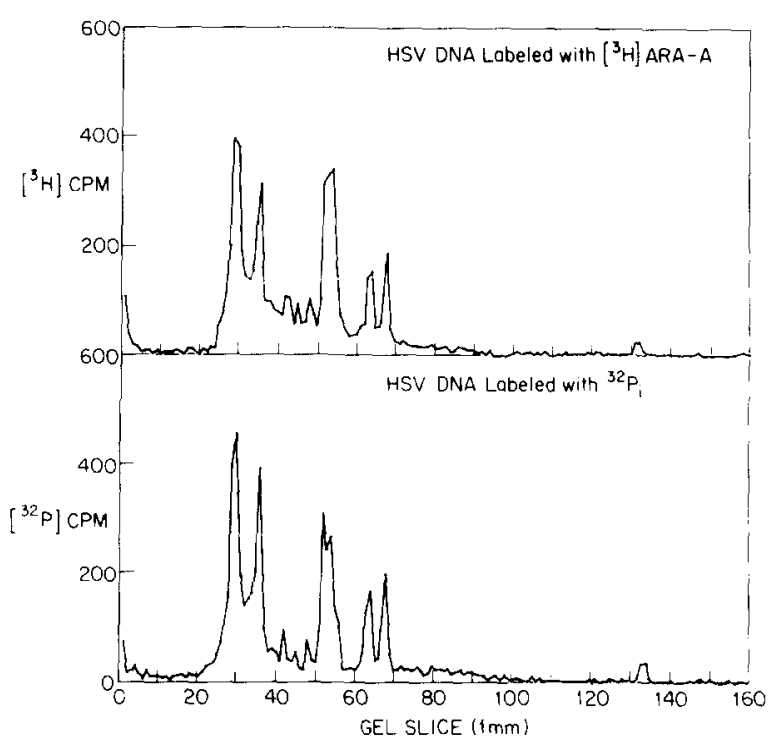

FIG. 5. Pattern of HindIII restriction endonuclease fragments of the HF strain of HSV-1. DNA isolated from mature virions (as depicted in the inset to Fig. 3) was labeled with $\left[{ }^{3} \mathrm{H}\right]$ ara-A (upper panel) or $\left[{ }^{32} \mathrm{P}\right]$ orthophosphate (lower panel). Approximately $1.5 \times 10^{4} \mathrm{cpm}\left[{ }^{3} \mathrm{H}\right.$ |ara-A-labeled $\mathrm{HSV}$ DNA (upper panel) and $2.3 \times 10^{4} \mathrm{cmm}^{32} \mathrm{P}$-labeled HSV DNA (lower panel) were layered onto cylindrical $0.6 \%$ agarose gels and electrophoresed as described under Materials and Methods.

phosphodiesterase experiments; namely, $\left[{ }^{3} \mathrm{H}\right]$ ara- $\mathrm{A}$ was incorporated into viral DNA as ara-AMP and this DNA was packaged during the replicative cycle into virions destined to be released by the infected cell.

\section{Pattern of Incorporation of Ara-A into the HSV-1 (HF Strain) Genome}

The pattern of incorporation of ara-A into the HSV-1 genome was examined to determine whether ara-A was preferentially incorporated into specific sites. HSV-1 DNA previously labeled with $1.0 \mu M\left[{ }^{3} \mathrm{H}\right]$ ara-A was isolated from mature virions (as depicted in the inset to Fig. 3) and digested with the restriction endonuclease HindIII. After separation of the viral DNA fragments by electrophoresis in $0.6 \%$ agarose, the cylindrical gels were sliced and the amount of radioactivity in each slice was determined in a scintillation spectrometer. As a control, ${ }^{32} \mathrm{P}$-labeled-HSV-1 DNA was also digested with $\mathrm{HindIII}$ and electrophoresed under identical conditions to provide a reference pattern of HSV-1 fragments. The results obtained after electrophoresing the $\left[{ }^{3} \mathrm{H}\right]$ ara-A-labeled DNA fragments and ${ }^{32}$ P-labeled DNA fragments are shown in Fig. 5. We observed no significant differences in the number of molecular weights of the DNA fragments containing incorporated $\left[{ }^{3} \mathrm{H}\right]$ ara-A (upper panel) or $\left[{ }^{32} \mathrm{P}\right]-$ orthophosphate (lower panel). This observation suggests that incorporation of $\left[{ }^{3} \mathrm{H}\right] \mathrm{ara}-\mathrm{A}$ into the HSV-1 (HF strain) genome is random and does not occur at preferential sites.

\section{Incorporation of $\left[{ }^{3} \mathrm{H}\right] \mathrm{ara}-\mathrm{A}$ into $K B$ Cell DNA}

In order to compare the extent of uptake of $\left[{ }^{3} \mathrm{H}\right]$ ara-A into viral and cellular DNA, suspension cultures of $\mathrm{KB}$ cells were labeled with $0.1,1.0$, or $3.2 \mu M\left[{ }^{3} \mathrm{H}\right]$ ara-A. The use of suspension cultures allowed the sampling of uniform aliquots of cells immediately after drug addition and at the end of the incubation period. This permitted a determination of the amount of DNA synthesized de novo and established a base value from which the specific activity of cellular DNA could be calculated. Table 2 lists the specific activities of cellular DNA and the number of 
ara-AMP molecules incorporated per 10,000 dAMP molecules at each of the three drug levels. As can be seen from this table, the specific activities and hence, the amount of incorporated $\left[{ }^{3} \mathrm{H}\right]$ ara-AMP increased as the concentration of $\left[{ }^{3} \mathrm{H}\right]$ ara- $\mathrm{A}$ in the external medium was increased. Although the uptake of $\left[{ }^{3} \mathrm{H}\right]$ ara-A into both cellular and viral DNA was linear as a function of drug concentration (see Discussion), the number of ara-AMP molecules incorporated per 10,000 dAMP residues was 1.8 - to 5.8 -fold higher in cellular DNA when compared with viral DNA.

\section{DISCUSSION}

Our ability to demonstrate internucleotide incorporation of ara-A into viral DNA has important implications with respect to the mechanism of action of ara-A. It has been hypothesized that ara-A may exert its selective inhibition of viral DNA synthesis in HSV-infected cells by acting as a chain terminator of DNA strand elongation in viral replication, yet be incorporated internally through internucleotide linkage in replicating cell DNA (Müller et al., 1977a). The experimental results presented in the present communication, however, are in opposition to those reported by Müller and his co-workers. In our hands, ara-A was incorporated internally as ara-AMP into HSV DNA via internucleotide linkage. The most plausible explanation for these differing results arises from the contaminating phosphatase activity we have shown to be present in some commercial preparations of spleen phosphodiesterase. This phosphatase activity, if left uninhibited during digestion of viral DNA containing incorporated ara-A, has the ability to convert any existing araAMP to ara-A. As a result, analysis of the digested DNA by thin-layer chromatography would indicate that a major portion of the incorporated label is present in nucleoside form, thereby resulting in the incorrect interpretation that ara- $\mathrm{A}$ is incorporated into replicating viral DNA strands as a chainterminating moiety. In our system, the use of $1 \mathrm{mM}$ EDTA in the digestion mixture inhibited the phosphatase activity while not affecting spleen phosphodiesterase. A less plausible explanation for the differing results is that Müller and co-workers performed their analysis on "heavy viral DNA" (Müller et al., 1977a, b), a species of DNA never observed by us. An even less satisfying explanation is that the differences are due to variability between virus strains and cell types.

Having demonstrated that ara- $\mathrm{A}$ was incorporated internally into HSV-1 DNA from infected-cell lysates, further studies were undertaken to determine whether this viral DNA could be packaged into newly made progeny virions. The question is important because it is possible that viral DNA containing ara- $A$ is recognized as defective and is never packaged into mature virions. There is also the possibility that repair enzymes remove the incorporated ara-A from newly synthesized strands of viral DNA before packaging occurs.

In carrying out these studies, HSV-1 DNA was isolated from virions which had been purified from the supernatant fluid of infected $\mathrm{KB}$ cells incubated in the presence of $\left[{ }^{3} \mathrm{H}\right]$ ara-A. By means of enzymatic digestion and subsequent chromatography, the presence of incorporated $\left[{ }^{3} \mathrm{H}\right]$ ara- $\mathrm{A}$ in packaged viral DNA was demonstrated clearly. Verification of these results was obtained through the use of a second method of enzymatic digestion and two-dimensional chromatography. As with HSV DNA isolated from infected-cell lysates, the $\left[{ }^{3} \mathrm{H}\right]$ ara-A found in virion-associated DNA was shown to be incorporated internally via internucleotide linkage.

To determine whether preferential sites of ara-A incorporation exist, the pattern of incorporation of ara-A into the HSV-1 genome was examined. If ara-A were acting as a chain terminator, one would expect that incorporation of $\left[{ }^{3} \mathrm{H}\right]$ ara- $\mathrm{A}$ would be limited to restriction endonuclease fragments containing initiation sites. Because the number of initiation sites is limited (Roizman, 1979), only a small number of fragments would be labeled. If ara- $A$ were not acting as a chain terminator, incorporation of $\left[{ }^{3} \mathrm{H}\right]$ araA would be observed in all restriction fragments. Analysis of HindIII-digested HSV- 
1 virion DNA labeled with $\left[{ }^{3} \mathrm{H}\right]$ ara- $\mathrm{A}$ did indeed establish that incorporation of araA into the viral genome was random. Such an outcome is consistent with the random incorporation of $\left[{ }^{3} \mathrm{H}\right]$ arabinosylcytosine (ara-C) into the replicating SV-40 DNA genome (Manteuil et al., 1974).

Although no difference was observed in the amounts of ara-A incorporated into areas of the genome delimited by the HindIII cleavage, it is possible that significant variation did exist at a level below that detected by the studies described herein. The use of restriction enzymes which cut HSV DNA into smaller fragments might be employed to study incorporation of ara-A into genomic regions of interest. Furthermore, recent success with in vitro transcription and translation systems using HSV-1 DNA (Holland et al., 1980) may make it possible to study the effects of incorporated ara-A on the accuracy of transcription and resultant translation products.

Even though ara-A was not a chain terminator of viral DNA synthesis, internal incorporation of ara-A into DNA could be reponsible for the selective antiviral activity of the drug. Helical aberrations in DNA structure induced by the incorporation of an arabinosyl nucleoside (Provenzale and Nagyvary, 1970) could lead to errors in DNA transcription and replication. If incorporation of ara-A into DNA is critically involved in the mode of action of the drug, then one might expect more incorporation into viral DNA than into cellular DNA. To test this hypothesis, the amount of ara-A incorporated into viral and cellular DNA was determined at several drug concentrations. The data in Table 2, however, illustrate that substantially more ara-A was incorporated into cellular DNA than into viral DNA. These results indicate that the amount of ara-A incorporated into DNA may not be the only factor operative in the ability of the drug to inhibit viral replication.

Internal incorporation of ara-A into cellular DNA already has been demonstrated by others (LePage, 1970; Plunkett and Cohen, 1975; Müller et al., 1975), but these reports did not measure the amount of incorporation as a function of varying drug concentrations in the external medium. An analysis of the data in Table 2 indicates that there is a linear relationship between the concentration of ara- $\mathrm{A}$ in the extracellular medium and the number of ara-AMP residues incorporated. Linear regression analysis yielded a slope of +8.12 and a coefficient of correlation of +1.000 for viral DNA and a slope of +51.0 and a coefficient of correlation of +0.998 for cellular DNA demonstrating a more extensive incorporation into cellular DNA. Although the slopes are very different, they represent only the overall outcome of a very complex series of reactions. In actuality, the rates of uptake might be identical and the differences in slope could reflect undetected processes such as the selective removal of arabinosyl nucleotides from viral DNA. Such excision could be performed by the exonuclease associated with the herpes simplex virus DNA polymerase (Knopf, 1979).

The findings in this paper have important implications with respect to the mechanism of action of ara-A. Although ara-A has been shown to selectively inhibit HSV-1 DNA synthesis at the drug concentrations used in these studies, our present data indicate that there is no apparent connection between this selective inhibition and the incorporation of ara-A into viral and cellular DNA. We conclude that the selective inhibition of HSV DNA replication cannot be attributed solely, if at all, to the internal incorporation of this fraudulent nucleoside into DNA.

\section{ACKNOWLEDGMENTS}

We thank Gary S. Hayward for helpful discussions and unpublished information concerning restriction endonuclease maps of the HF strain of HSV-l, and Charles J. Kowalski for expert advice in the statistical interpretation of the data. The assistance of Sandra $\mathrm{H}$. Smith in carrying out diphenylamine assays is gratefully acknowledged. During a portion of this work, J. C. P. was supported by a Frederick G. Novy Fellowship awarded by the Department of Microbiology, The University of Michigan. This investigation was supported by USPHS Grant DE 02731 from the National Institute of Dental Research.

\section{REFERENCES}

BurTon, K. (1968). Determination of DNA concentration with diphenylamine. In "Methods in Enzymol- 
ogy" (L. Grossman and K. Moldave, eds.), Vol. 12, Part B, pp. 163-166. Academic Press, New York.

Cohen, G. H., Vaughan, K. K., and Lawrence, W. C. (1971). Deoxyribonucleic acid synthesis in synchronized mammalian $\mathrm{KB}$ cells infected with herpes simplex virus. $J$. Virol. 7, 783-791.

FLANAGAN, J. F. (1967). Virus-specific ribonucleic acid synthesis in $\mathrm{KB}$ cells infected with herpes simplex virus. J. Virol. 1, 583-590.

Hilmoe, R. J. (1960). Purification and properties of spleen phosphodiesterase. J. Biol. Chem. 235, 2117-2121.

Holland, L. E., Anderson, K. P., Shipman, C., JR., and WAGNER, E. K. (1980). Viral DNA synthesis is required for the efficient expression of specific herpes simplex virus type $1 \mathrm{mRNA}$ species. Virology 101, 10-24.

HorRocks, D. L. (1974). "Applications of Liquid Scintillation Counting." Academic Press, New York.

.Josse, .J., Kaiser, A. D., and KornBerg, A. (1961). Enzymatic synthesis of deoxyribonucleic acid. VIII. Frequencies of nearest neighbor base sequences in denxyrihonucleic acid. I. Biol. Chem. 236, 864-875.

KLEIN, R. J. (1975). Isolation of herpes simplex virus clones and drug resistant mutants in microcultures. Arch. Virol. 49, 73-80.

KNOPF, K.-W. (1979). Properties of herpes simplex virus DNA polymerase and characterization of its associated exonuclease activity. Eur. J. Biochem. 98, 231-244.

KURTz, S. M. (1975). Toxicology of adenine arabinoside. In "Adenine Arabinoside: An Antiviral Agent" (D. Pavan-Langston, R. A. Buchanan, and C. A. Alford, Jr., eds.), pp. 145-157. Raven Press, New York.

LEPAGE, G. $\Lambda$. (1970). Arabinosyladenine and arabinosylhypoxanthine metabolism in murine tumor cells. Canad. J. Biochem. 48, 75-78.

Manteuil, A., Kopecka, H., Caraux, J., Prunell, A., and GIRARD, M. (1974). In vivo incorporation of cytosine arabinoside into simian virus 40 DNA. $J$. Mol. Biol. 90, 751-756.

MUtller, W. E. G., Rhode, H. J., Beyer, R., Maidhof, A., Lachmann, M., Taschner, H., and ZAHN, R. (1975). Mode of action of 9- $\beta$-D-arabinofuranosyladenine on the synthesis of DNA, RNA, and protein in vivo and in vitro. Cancer Res. 35, 2160-2168.

MÚller, W. E. G., ZahN, R. K., Beyer, R., and FALKE, D. (1977a). 9- $\beta$-D-arabinofuranosyladenine as a tool to study herpes simplex virus DNA replication in vitro. Virology 76, 787-796.

MÚller, W. E. G., Zahn, R. K., BitTlingmaier, K., and FALKE, D. (1977b). Inhibition of herpesvirus DNA synthesis by $9-\beta$-D-arabinofuranosyladenine in cellular and cell-free systems. Ann. N. Y. Acad. Sci. 284, 34-48.

Pavan-Langston, D. (1975). Clinical evaluation of adenine arabinoside and idoxuridine in treatment of routine and idoxuridine-complicated herpes simplex keratitis. In "Adenine Arabinoside: An Antiviral Agent" (D. Pavan-Langston, R. A. Buchanan, and C. A. Alford, Jr., eds.), pp. 345-356. Raven Press, New York.

PlunketT, W., and Cohen, S. S. (1975). Metabolism of 9- $\beta$-D-arabinofuranosyladenine by mouse fibroblasts. Cancer Res. 35, 415-422.

Provenzale, R. G., and Nagyvary, J. (1970). Synthesis and structure of polyarabinouridylic acid. Biochemistry 9, 1744-1752.

RoIZMAN, B. (1979). The structure and isomerization of herpes simplex virus genomes. Cell 16, 481-494.

Schwartz, P. M. (1975). Ph.D. thesis, The University of Michigan. University Microfilms, Ann Arbor, Mich. (Diss. Abst. 36, 2708B, 1975).

Schwartz, P. M., and DraCH, J. C. (1978). Thinlayer chromatography of purine bases, nucleosides, and nucleotides. In "Nucleic Acid Chemistry, Improved and New Synthetic Procedures, Methods and Techniques" (L. B. Townsend and R. S. Tipson, eds.), Part 2, pp. 1061-1067. Wiley, New York.

Schwartz, P. M., Shipman, C., Jr., and Drach, J. C. (1976). Antiviral activity of arabinosyladenine and arabinosylhypoxanthine in herpes simplex virusinfected KB cells: Selective inhibition of viral deoxyribonucleic acid synthesis in the presence of an adenosine deaminase inhibitor. Antimicrob. Agents Chemother. 10, 64-74.

Shannon, W. M. (1975). Adenine arabinoside: Antiviral activity in vitro. In "Adenine Arabinoside: An Antiviral Agent" (D. Pavan-Langston, R. A. Buchanan, and C. A. Alford, Jr., eds.), pp. 1-43. Raven Press, New York.

SHIPMAN, C., JR. (1969). Evaluation of 4-(2-hydroxyethyl)-1-piperazineëthanesulfonic acid (HEPES) as a tissue culture buffer. Proc. Soc. Exp. Biol. Med. 130, 305-310.

Shipman, C., JR., Smith, S. H., Carlson, R. H., and DRACH, J.C. (1976). Antiviral activity of arabinosyladenine and arabinosylhypoxanthine in herpes simplex virus-infected KB cells: Selective inhibition of viral deoxyribonucleic acid synthesis in synchronized suspension cultures. Antimicrob. Agents Chemother. 9, 120-127.

SLOAN, B. J. (1975). Adenine arabinoside: Chemotherapy studies in animals. In "Adenine Arabinoside: An Antiviral Agent” (D. Pavan-Langston, R. A. Buchanan, and C. A. Alford, Jr., eds.), pp. 45-94. Raven Press, New York.

Stringer, J. R., Holland, L. E., and WAGner, E. K. (1978). Mapping early transcripts of herpes simplex virus type 1 by electron microscopy. J. Virol. 27, $56-73$.

Whitley, R. J., SOONG, S.-J., Dolin, R., Galasso, G. J., CH'IEN, L. 'T., and ALFord, C. A., JR. (1977). Adenine arabinoside therapy of biopsy-proved herpes simplex encephalitis. N. Engl.J. Med. 297, 289-294. 